\title{
Religious Democracy and Civilizational Politics: Comparing Political Islam and Political Catholicism
}

\section{Michael Driessen}

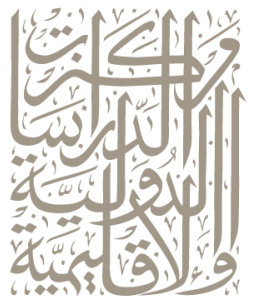

CIRS

CENTER FOR INTERNATIONAL AND REGIONAL STUDIES

GEORGETOWN UNIVERSITY SCHOOL OF FOREIGN SERVICE IN QATAR 


\section{Religious Democracy and Civilizational Politics: Comparing Political Islam and Political Catholicism}

Michael Driessen

(C) 2013 Center for International and Regional Studies Georgetown University School of Foreign Service in Qatar

Occasional Paper No. 12

ISSN 2072-5957 


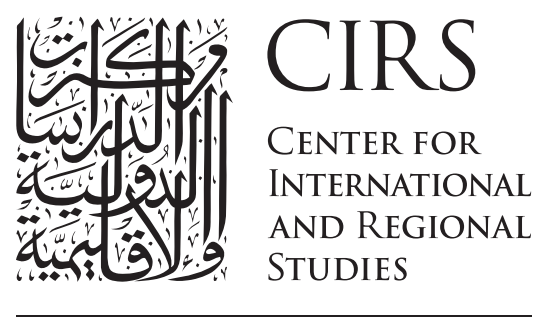

GEORGETOWN UNIVERSITY

SCHOOL OF FOREIGN SERVICE IN QATAR

Established in 2005, the Center for International and Regional Studies at the Georgetown University School of Foreign Service in Qatar is a premier research institute devoted to the academic study of regional and international issues through dialogue and exchange of ideas, research and scholarship, and engagement with national and international scholars, opinion makers, practitioners, and activists.

Guided by the principles of academic excellence, forward vision, and community engagement, the Center's mission revolves around five principal goals:

- To provide a forum for scholarship and research on international and regional affairs

- To encourage in-depth examination and exchange of ideas

- To foster thoughtful dialogue among students, scholars, and practitioners of international affairs

- To facilitate the free flow of ideas and knowledge through publishing the products of its research, sponsoring conferences and seminars, and holding workshops

designed to explore the complexities of the twenty-first century

- To engage in outreach activities with a wide range of local, regional, and international partners.

This publication series is made possible by the generous support of Qatar Foundation for Education, Science and Community Development. 


\section{Religious Democracy and Civilizational Politics: Comparing Political Islam and Political Catholicism}

Michael Driessen

Michael Driessen is Assistant Professor of Political Science and International Affairs at John Cabot University in Rome, Italy. He obtained his Ph.D. in Political Science from the University of Notre Dame in the US, and in 20112012 was a resident Post-Doctoral Fellow at Center for International and Regional Studies (CIRS), Georgetown University School of Foreign Service in Qatar. Driessen's research interests include Islamic and Catholic political movements, democratization studies, peace studies, and the politics of southern Europe, North Africa, and the Middle East. While at CIRS, Driessen finished a book manuscript titled Religion and Democratization: Framing Political and Religious Identities in Catholic and Muslim Societies, which is forthcoming with Oxford University Press (2014). The book explores how religion-state arrangements help frame questions of religious and political identity in Muslim and Catholic societies in southern Europe and North Africa. 


\begin{abstract}
Much of the recent literature on the evolution of political Islam in the Middle East and North Africa has debated the extent to which Islamist political parties have become "secularized" in their political goals and rhetoric. In these studies, a comparison between the political secularization of Islamism and Christian Democracy is often alluded to, but rarely explored in depth. The two political religious movements share much in common with regards to their historical encounter with political liberalism and their intuitions about an ideal religious society. An uncritical comparison, however, obscures significant differences in the relationship of either movement to democratic institutions, traditional sources of religious authority, and the religious citizens of their nations. This paper qualifies the historical, institutional, and theological similarities of political Islam and political Catholicism. In doing so, it emphasizes the importance of the legacies of Catholic Christendom and Muslim Dar al-Islam as transnational, pre-Westphalian religious political orders and the idea of religious authority found in either. After articulating these bases of comparison, the paper considers how these religious legacies remain present in the transition to Christian or Muslim Democracies by exploring the rhetoric of Catholic civilization or Muslim civilization found in Pope Pius XII and Rachid Ghannouchi's discourses on democracy.
\end{abstract}




\section{Introduction}

Much recent scholarship on political Islam has focused on the tendency of Islamist or post-Islamist parties to "moderate" their political goals and rhetoric over time as they participate in electoral politics and become institutionalized as political parties. In observing this process, scholars have often evoked a strong comparative appeal to political Catholicism and the experience of Christian Democratic parties in Europe, ${ }^{1}$ although the comparison has only rarely been explored systematically. ${ }^{2}$ Equally interesting, Islamist or Islamist-inspired political parties have also explicitly evoked the comparison, including the Movement for Society and Peace (MSP) in Algeria, ${ }^{3}$ the Justice and Development Party (AKP) in Turkey, ${ }^{4}$ the Muslim Brotherhood in Egypt, ${ }^{5}$ and Ennahda in Tunisia.

\footnotetext{
${ }^{1}$ Stathis N. Kalyvas, "Commitment Problems in Emerging Democracies: The Case of Religious Parties," Comparative Politics (2000): 379-398; Stathis N. Kalyvas, "Unsecular Politics and Religious Mobilization: Beyond Christian Democracy," in European Christian Democracies: Historical Legacies and Comparative Perspectives, ed. Thomas A. Kselman and Joseph A. Buttigieg (Notre Dame, IN: University of Notre Dame Press, 2003), 293-320; S. Vali R. Nasr, "The Rise of 'Muslim Democracy," Journal of Democracy 16, no. 2 (2005): 13-27; William Hale, "Christian Democracy and the AKP: Parallels and Contrasts," Turkish Studies 6, no. 2 (2005): 293-310; P. Michael Minkenberg, "Democracy and Religion: Theoretical and Empirical Observations on the Relationship between Christianity, Islam, and Liberal Democracy," Journal of Ethnic and Migration Studies 33, no. 6 (2007): 887-909; Amel Boubekeur, "Post-Islamist Culture: A New Form of Mobilization?," History of Religions 47, no. 1 (2007): 75-94; Philip S. Gorski and Ateş Altınordu, "After Secularization?" Annual Review of Sociology 34 (2008): 55-85; Mirjam Künkler and Julia Leininger, "The Multi-faceted Role of Religious Actors in Democratization Processes: Empirical Evidence from Five Young Democracies," Democratization 16, no. 6 (2009): 1058-1092; Ahmet T. Kuru, Secularism and State Policies Toward Religion: The United States, France, and Turkey (Cambridge: Cambridge University Press, 2009); Nader Hashemi, Islam, Secularism, and Liberal Democracy: Toward a Democratic Theory for Muslim Societies (Oxford: Oxford University Press, 2009); Ateş Altınordu, "The Politicization of Religion: Political Catholicism and Political Islam in Comparative Perspective," Politics E Society 38, no. 4 (2010): 517 551; Stathis N. Kalyvas and Kees Van Kersbergen, "Christian Democracy," Annual Review of Political Science 13 (2010): 183-209; José Casanova, "Religion, Politics and Gender Equality: Public Religions Revisited," A Debate on the Public Role of Religion and its Social and Gender Implications, Gender and Development Programme Paper 5, United Nations Research Institute for Social Development (2009): 5-33; José Casanova, "Civil Society and Religion: Retrospective Reflections on Catholicism and Prospective Reflections on Islam," Social Research 68, no. 4 (2001): 1041-1080; Khaled Helmy, "The Historical Process of State Regulation of Religion and Its Democratic Implications" (paper prepared for presentation at the 10th Mediterranean Research Meeting, European University Institute, Robert Shuman Center for Advanced Studies, Montecatini, Italy, March 25-28, 2009).

${ }^{2}$ Altınordu, "The Politicization of Religion;" Casanova, "Civil Society and Religion;" and Helmy, "The Historical Process of State Regulation of Religion" are the exceptions in this scholarship. There is, of course, a vast literature exploring the comparability of Islam and Catholicism on other grounds. For an excellent introduction to the comparison of Christianity and Islam as religions with respect to their conceptions of the state, see L. Carl Brown, Religion and State: The Muslim Approach to Politics (New York: Columbia University Press, 2000).

${ }^{3}$ Boubekeur, "Post-Islamist Culture;" Michael Driessen, "Public Religion, Democracy, and Islam: Examining the Moderation Thesis in Algeria," Comparative Politics 44, no. 2 (2012): 171-189.

${ }^{4}$ The AKP applied for membership in 2003 to the European Peoples' Party, an organization of Christian Democratic Parties in Europe. The AKP has not been granted member status to the organization but is currently an "observer" member. Additionally, the Democratic League of Kosovo, which some consider to be an Islamic Party, is also a member of the Christian Democratic International-the international organization of Christian Democratic Parties.

${ }^{5}$ The Muslim Brotherhood, for example, recently highlighted on their official website an article by Germany's Foreign Minister, Guido Westerwelle, in which he compares the Brotherhood to the Christian Democratic parties of Europe. Westerwelle currently works with such a Christian Democratic party in coalition in the present German government. See "Political Islam and Democracy, by German Foreign Minister Guido Westerwelle," on the Ikhwan website, January 18, 2012, http://www.ikhwanweb.com/article.php?id=29566.
} 
This evocation has taken on considerable importance as Islamist-oriented parties have dominated the inaugural elections of several of the political transitions of the Arab Spring. As these parties have ascended to power, many have wondered whether a party which defends the prerogatives of a state religion will also fully protect democratic liberties of expression and association. Faced with these doubts, the analogy of Christian Democracy has served as a legitimating device for Islamist parties to use as proof that religious goals can be pursued in a fully-functioning democratic environment. ${ }^{6}$ At the same time, the experience of Christian Democracy has also provided an historical model of religious democracy for Islamists, one which they can improve upon to better achieve their goals. As constituent assemblies formed in both Tunisia and Egypt in 2012, in fact, a number of cross-Mediterranean initiatives brought together scholars of Christian Democracy in Europe with Islamist party leaders from Egypt, Tunisia, and Turkey. ${ }^{7}$ These initiatives attempted to give Islamist leaders the opportunity to scour the Christian Democratic experience for insight into their present political tasks and religious hopes. The lessons drawn from this comparison between political Islam and political Catholicism, thus, are not only academically interesting, but will also have real consequences for the future goals and policies of Islamist-inspired political parties in the Middle East and North Africa today. ${ }^{8}$ As such, the validity of the comparison merits closer attention.

The appeal of the comparison arises from three basic considerations, namely, that Islamist-inspired and Christian Democratic parties 1) share a similar founding religious reference, inspiration, and world-view; 2) possess similar policy orientations; ${ }^{9}$ and 3) have been subject to a similar political evolution: both sets of parties grew out of religious-political movements that were originally thought to be hostile towards democratic ideas and institutions before becoming protagonists in the transitions and consolidation of democracy in their countries.

These considerations also make at least two background assumptions, namely, that there is a reasonable level of similarity between the nature of Islam and Catholicism

\footnotetext{
${ }^{6}$ Nasr, "The Rise of 'Muslim Democracy."

${ }^{7}$ These include conferences held in Tunisia by the Konrad Adenauer Stiftung of Germany's Christian Democratic Union; in Italy, by the Italian Ministry of State; and in Lebanon, by the inter-religious organization Adyan.

${ }^{8}$ It should be noted here that it is not clear whether the Islamist-inspired parties themselves draw the same conclusions about Christian democracy as the scholars do. In a typical exchange at a conference, whereas the historians emphasized the inclusive political framework adopted by Christian Democratic parties in post-war Europe, several religious actors in the Tunisian audience reminded the historians that it was a crime in Italy to publicly offend the pope, as, indeed, it technically was until a 2006 change in the Italian penal code; see Michael Driessen, Religion and Democratization: Framing Political and Religious Identities in Catholic and Muslim Societies (New York: Oxford University Press, forthcoming).

${ }^{9}$ Some have characterized these policies as center-right and conservative; Hale, "Christian Democracy and the AKP: Parallels and Contrasts;" although it is probably better to think of them, following Kalyvas and Van Kersbergen, "Christian Democracy," as catch-all, heterogeneous parties with their own particular blend of policies and styles.
} 
as religions, and the nature of the hostility which actors in either tradition assumed towards democracy. If Islam and Catholicism cannot be meaningfully compared as religions, or, even if they can, if the hostility of religious actors towards democracy in either tradition emanated from disparate sources, it is difficult to expect that democratization processes would have had the same effects on religious actors in both Catholic and Muslim settings. If, for example, Catholicism is an inherently more flexible religion than Islam is with respect to politics, or if Catholic suspicions towards democracy are less theologically rooted than Muslim suspicions, then we might have more reason to believe that Catholic actors, but not necessarily Muslim actors, would drop their religious goals more readily in a democratic environment. Or, even if the effects of democratization on the evolution of religious goals and ideas look strikingly similar in both predominantly Muslim and Catholic settings, one might still argue that the effects had occurred for different and idiosyncratic reasons.

Given the active attempt of Islamist parties and scholars to draw lessons from the experience of Christian Democracy, the basic aim of this paper is to address the validity of this comparison and qualify the historical, institutional, and theological similarities between political Catholicism and political Islam. In addressing the background of this comparison, however, the paper also has a second, more theoretical ambition, which is to better articulate the dynamics at work between religious politics and democratic society. Here, specifically, I want to reflect on what might be important about the fact that these parties are religious parties. In what ways would we expect the religious nature of these parties to translate into a new democratic space and make these Muslim or Catholic democracies different from their more secular counterparts? And how does their specificity as Catholic or Muslim parties affect the possible shape of these regimes? In analyzing the relationship between religion and democracy, contemporary scholarship in the social sciences still gravitates towards two polar approaches, alternatively investing religious ideas and traditions with an over-determinate force on political outcomes or stripping religious ideas and traditions of any particular effect which could not be attributed to other factors. Neither of these approaches is wholly satisfying, and a paired study of political Catholicism and political Islam presents us with an opportunity to navigate between these two impulses. In doing so, we can engage in a critical comparison which does not ignore the religious element of either political party nor obscure the significant differences in their particular relationships to democratic institutions, traditional sources of religious authority, or the religious citizens of their nations.

In order to achieve these two aims, the rest of the paper proceeds as follows. The first section considers the importance of this comparison for contemporary research on Islam and democracy. It then begins to approach the comparison between Catholic and Muslim experiences with democracy by introducing a theoretical approach to the study of religion and politics which incorporates both institutional and ideational 
dynamics. The second section draws on this approach to analyze the comparison between political Islam and political Catholicism. Specifically, the section considers the nature of Islam and Catholicism as faith traditions, and the history, the theology, and the institutions which created the backdrop for the hostile stances assumed by religious political movements in either tradition. Throughout this section, I emphasize the importance of the experience and legacies of Catholic Christendom and early Muslim Dar al-Islam ${ }^{10}$ as transnational, pre-Westphalian religious political orders and the idea of religious authority found in either. The legacies of this experience shaped not only the original hostility of political Islam and political Catholicism to democracy but also the democratic visions that either movement eventually adopted for their respective societies. In both the hostility towards and the eventual embrace of democracy by political Islam and political Catholicism, I will argue, we can recognize a similar, constant intuition about the role of religious authorities to shape and underwrite society and politics. The third section, therefore, considers how this religious legacy remains present in the transition to Christian Democratic and Muslim Democratic parties and, as an illustration, highlights the rhetoric of Catholic civilization or Muslim civilization found in Pope Pius XII and Rachid Ghannouchi's discourses on democracy. ${ }^{11}$ The final, concluding section considers the role of the institutional specificities of either faith tradition in the new formations of religious power favored in Christian or Muslim Democracies.

\section{Analyzing Contentious Religious Politics}

As mentioned earlier, one of the prevalent trends within current scholarship on political Islam is to observe the tendency of Islamist political parties to moderate, secularize, and incorporate themselves into the political regimes of their countries over time. One of the hallmarks of this literature is that it largely discounts the overwhelming power that was often attributed to an idealized version of Islamic political theology in earlier debates about Islam and democracy. In what has been coined the "inclusion-moderation hypothesis, ${ }^{12}$ several scholars have argued that the original hostility of Islamist parties to democracy derives more from their exclusion from politics than from irreconcilable

\footnotetext{
${ }^{10}$ Dar al-Islam literally means the "House of Islam," referring to the wider collection of Muslim societies in which Islam could be practiced freely and where Muslims represent the majority of the population. Here, specifically, the term is used to reference the geo-political zone of early Muslim conquest in the first centuries following the death of the Prophet Muhammad.

${ }^{11}$ Both Pope Pius XII and Rachid Ghannouchi, as we will see, offered important religious endorsements of democracy at key moments in the history of political Islam and political Catholicism. Pius XII reigned as pope during Italy's post-war democratization process, and mobilized much of the Catholic Church's resources in support of the Italian Christian Democratic Party. Ghannouchi is the founder of the Tunisian Islamist-oriented party "Ennahda." After years in exile, he returned to Tunisia in 2011 following the fall of President Ben 'Ali and subsequently led his party to a stunning electoral victory later that year.

${ }^{12}$ Jillian Schwedler, Faith in Moderation: Islamist Parties in Jordan and Yemen (Cambridge: Cambridge University Press, 2006).
} 
theological precepts. ${ }^{13}$ Islamist religious beliefs and political goals have changed over time, these scholars argue, and including Islamist parties in democratic processes helps stimulate the democratic elements within their political programs, leading them and their constituents to become more politically secular and democratic.

This scholarship, in several ways, could be read as a response from within the social sciences to essentialist claims from the 1990s and early 2000s about the fundamental incompatibilities that exist between Islamic values and democratic ideals. ${ }^{14}$ For these scholars, theology and history had conspired against democracy in the Middle East. Theologically, the essentialists pointed out, it was much more difficult, if not impossible, in Islam to justify a political order whose legitimacy resided in a constitutional contract with "the people," rather than in an explicit submission to the sovereignty of God's authority. Perhaps one of the most famously referenced scriptures in support of such a claim is from Al-Zumar, 39:6 of the Qur'an, which says: ${ }^{15}$

He formed you in the mother's womb,

Formation after formation

In three (veils of) darkness.

He is God your Lord.

His is the kingdom. ${ }^{16}$

There is no god other than He.

What is more, historically, the essentialists argued, the Prophet Muhammad and his four companions who succeeded him were successful conquerors and military leaders. ${ }^{17}$ Islam's founding moment, therefore, also seemed to sanction an undemocratic fusion

\footnotetext{
${ }^{13}$ François Burgat and William Dowell, The Islamic Movement in North Africa (Austin: Center for Middle Eastern Studies, University of Texas at Austin, 1993); Carrie R. Wickham, "The Path to Moderation: Strategy and Learning in the Formation of Egypt's Wasat Party," Comparative Politics (2004): 205-228; Schwedler, Faith in Moderation; Jillian Schwedler, "Can Islamists Become Moderates? Rethinking the Inclusion-Moderation Hypothesis," World Politics 63, no. 02 (2011): 347-376; Gunę̧ M. Tezcür, “The Moderation Theory Revisited The Case of Islamic Political Actors," Party Politics 16, no. 1 (2010): 69-88.

${ }^{14}$ Bernard Lewis, “The Roots of Muslim Rage," The Atlantic 17, no. 4 (1990): 17-26; Samuel P. Huntington, The Class of Civilizations and the Remaking of World Order (New Delhi: Penguin, 1997); Martin Kramer, "The Mismeasure of Political Islam," The Islamism Debate (1997): 161-175; Daniel Pipes, In the Path of God: Islam and Political Power (New Jersey: Transaction Books, 1983); Bassam Tibi, "Why They Can't Be Democratic," Journal of Democracy 19, no. 3 (2008): 43-48.

${ }^{15}$ Often cited is also from sura Al-Baqarah, 2:25 of the Qur'an: He to whom belongs the kingdom of the heavens and the earth/Who has neither begotten a son /Nor has He a partner in His kingdom/ (who) created every thing/ And determined its exact measure.

${ }^{16}$ Here, in which "kingdom" is often translated as "sovereignty," but not without controversy; Lahouari Addi, L'Algérie Et La Démocratie: Pouvoir Et Crise Du Politique Dans l'Algérie Contemporaine [Algeria and democracy: Power and political crisis in contemporary Algeria], (La Découverte, 2010), for example, argues that the term "sovereignty" is a modern concept and can only be understood as a characteristic of modern, post-Westphalian political regimes, not the "Kingdoms" to which the Qur'an alludes. See also Olivier Roy, The Failure of Political Islam (Cambridge, MA: Harvard University Press, 1994).

${ }^{17}$ The four Rashidun Caliphs, Abu Baker, 'Umar, 'Uthman, and 'Ali.
} 
of religious and political authority. Early Islamist ideologues, like Mawdudi and Qutb, made exactly this argument when they appealed to the sovereignty of God and the example of early Islamic governance to argue for the political re-establishment of an Islamic state in modernity. Since there is no legitimate authority outside the authority of God, they claimed, then all righteous political projects ought to unite religious and state institutions and legislate religious (Shari'a) law. ${ }^{18}$ Qutb went so far as to state that all societies that compromised the sovereignty of God with man-made laws, including nominally Muslim societies, were living in corruptive ignorance and thus became legitimate targets for the waging of jibad, or holy war. ${ }^{19}$ It is for this reason that Roy claims that, while not necessarily violent, Islamism is, by definition, undemocratic. ${ }^{20}$

The reference category of comparison, especially for Huntington and Lewis, was the Christian West. Christianity's founder was not interested in politics, they argued and had commanded to "Give to Caesar what is Caesar's and to God what is God's."21 Much of the essentialist argument could be boiled down to this historical-theological reading of Matthew's verse from the New Testament and the type of religious authority it seemed to prescribe for society. ${ }^{22}$ For the essentialists, it meant that Christianity was naturally predisposed towards the political differentiation from religious authority which had eventually made democracy possible in the West. In making this argument, Huntington, Lewis, and others put a classical emphasis on the role of the Protestant Reformation in Western history and the way in which it broke the political power of Catholic religious elites, ${ }^{23}$ gave rise to the modern Western nation-state, and endowed Protestant societies with certain affinities to modern democracy. ${ }^{24}$

\footnotetext{
${ }^{18}$ Which, many worried, would grant wide powers to non-elected religious authorities to marginalize the individual rights of secular and other (and less) religious citizens, see Kramer, "The Mismeasure of Political Islam." ${ }^{19}$ Qutb famously condemned these societies as living in Jabiliyya, as in the time of pre-Islamic ignorance.

${ }^{20}$ Olivier Roy, Globalized Islam: The Search for a New Ummah (New York: Columbia University Press, 2004), 60.

${ }^{21}$ Huntington, The Clash of Civilizations, 210; Lewis, "The Roots of Muslim Rage,"1.

${ }^{22}$ Huntington cites the verse as Mt 22:21 although it can be found in Lk 20:25 or Mk 12:17 as well.

${ }^{23}$ For a more detailed analysis of Luther's political theology of secular authority which animated much of the Protestant Reformation and "the Two Kingdoms and the Two Governments," see Daniel Philpott, "The Religious Roots of Modern International Relations," World Politics 52, no. 2 (2000): 206-245; Robert W. Lovin, Christian Realism and the New Realities (Cambridge: Cambridge University Press, 2008); Michael A. Gillespie, The Theological Origins of Modernity (Chicago: University of Chicago Press, 2008).

${ }^{24}$ By creating an individual sense of calling-Max Weber, The Protestant Ethic and the "Spirit" of Capitalism and Other Writings, ed. and trans. Peter Baehr and Gordon C. Wells (New York: Penguin Classics, 2002)—and societal self-discipline-Philip S. Gorski, The Disciplinary Revolution: Calvinism and the Rise of the State in Early Modern Europe (Chicago: University of Chicago Press, 2003) - and setting the entrepreneurial capacities of the authoritarian spiritual power of Rome, which was anathema to the promotion of mutual trust, individual political choice, and political liberties; E. C. Banfield, The Moral Basis of a Backward Society (New York: Free Press, 1967); Gabriel A. Almond and Sidney Verba, The Civic Culture: Political Attitudes and Democracy in Five Nations (London: Sage Publications, 1989); Robert Putnam, Making Democracy Work: Civic Traditions in Modern Italy (New Jersey: Princeton University Press, 1994); Max Weber, Economy and Society: An Outline of Interpretive Sociology, vol. 1 (Berkeley: University of California Press, 1978).
} 
In his challenge of the political corruption of the Catholic Church, Luther could turn to the early history of Christianity and a wealth of theological resources that reminded Christians just how wary they should be of earthly kingdoms. Before the Catholic Church became explicitly identified with a political regime through the Roman Emperor Constantine, Christians had rejoiced in their rejection by the world's political powers. Christians had welcomed this rejection as a mark of their belonging to the heavenly kingdom revealed to them by their founder, Jesus of Nazareth, who refused to establish any political order on this earth and was put to death by the Roman Empire. ${ }^{25}$ In this light, the monastic tradition and even the institutionalization of the Church's clerical hierarchy could be interpreted as attempts to articulate the Church's separate nature from political authority, making it clear that the Church's first allegiance was to what Augustine had distinguished as the divine "city of God" as opposed to the political "earthly city." In this respect, therefore, the Protestant Reformation could be understood as a lengthy corrective to an institutionalized relationship between religion and politics which had led to spiritual and political corruption. This reform finally reached the Catholic Church at the Second Vatican Council, in which the Catholic hierarchy voted to make itself more ideationally and institutionally similar to Protestantism and, thus, by extension, to the early Christian Church. ${ }^{26}$

The explanatory power accredited to religious ideas and history by the essentialists sits in sharp contrast to the scholarship on the "inclusion-moderation hypothesis," 27 which emphasizes the ways in which religious political actors are constrained by the same strategic calculations and institutional dynamics as other political actors. Many political scholars of Christian Democracy embrace a similar approach: as Warner writes of Christian Democratic parties in her book Confessions of an Interest Group, "The Catholic Church is an interest group whose actions can be modeled as if it were a firm in a market seeking a supplier of goods. ${ }^{28}$ For the inclusion-moderation hypothesis

\footnotetext{
${ }^{25}$ Jesus taught his followers that they would have to lose their life to gain the heavenly kingdom (Lk 9:23-24) and explicitly told the Roman Procurate Pontius Pilate that, "My Kingdom is not of this world. If my kingdom were of this world, my servants would fight, so that I should not be delivered to the Jews; but now my kingdom is not from here" (Jn 18:36, see also Mt 26:43).

${ }^{26}$ The "Protestant-izing" reforms of Vatican II, in turn, it could be argued, liberated Catholics all over the world to embrace democratic rights and institutions and, it has been argued, as a result, to protest authoritarian politics, making the Catholic Church one of the great agents of change behind the third wave of democracy throughout the 1970s and 1980s - a point that did not escape Huntington's notice; Samuel P. Huntington, "Democracy's Third Wave," Journal of Democracy 2, no. 2 (1991): 12-34; Daniel Philpott, “The Catholic Wave," Journal of Democracy 15, no. 2 (2004): 32-46; John Anderson, "The Catholic Contribution to Democratization's 'Third Wave': Altruism, Hegemony or Self-interest?," Cambridge Review of International Affairs 20, no. 3 (2007): 383-399; Monica D. Toft, Daniel Philpott, and Timothy S. Shah, God's Century: Resurgent Religion and Global Politics (New York: W.W. Norton, 2011).

${ }^{27}$ Wickham, "The Path to Moderation;" Schwedler, Faith in Moderation; Schwedler, "Can Islamists Become Moderates?;” Tezcür, "The Moderation Theory."

${ }^{28}$ Carolyn M. Warner, Confessions of an Interest Group: The Catholic Church and Political Parties in Europe (New Jersey: Princeton University Press, 2000), 4.
} 
and other scholars modeling religious parties as interest groups, therefore, political praxis shapes political ideology and determines what interpretation religious-political entrepreneurs will ultimately attribute to their religious traditions.

This emphasis on the instrumental nature of religious ideas has been helpful in identifying democratic possibilities that include Islamist parties and some version of their ideology. Their scholarship forces scholars to carefully analyze the actual practices of religious actors rather than simply their beliefs, which do not always match up with their actions. Finally, it also seems to better explain the current evolution of Islamistinspired political parties, including the active role many are playing in the democratic life of their countries (something the essentialists would not have expected). While some question whether Islamists have really become "true believers" in democracy, the fact that Islamist parties from Tunisia to Turkey to Egypt have participated in elections; recognized multi-party parliaments; and announced their willingness to abide by majority-voted laws (whether religiously favorable or not) represents a break from earlier Islamist rejections of all three. ${ }^{29}$

Yet, in this drive to argue that praxis shapes ideology, strategic-actor approaches to religious parties have generally failed to take stock of the full influence of religious ideas and actors over society and politics even in newly democratized settings where religious parties appear to have moderated their religious demands. ${ }^{30}$ Part of the problem here is that the moderation or incorporation of religious actors into a democratic setting is still often defined in some way as a function of their secularization. Kalyvas, for example, explicitly writes that parties that moderate, "decrease the saliency of their religious goals and accept operating within competitive and secular institutional frames." ${ }^{31}$ Under these terms, party moderation itself is defined as party secularization and the possibility of religious politics in future democratic regimes is effectively excluded-its re-appearance or persistence is registered as a regression from democracy instead of a new approach capable of shaping democracy in different ways.

What I want to argue here is that the influence of political praxis on ideological goals is never a one-way street. Thus, even though strategic political calculations at one point in time might prompt religious actors to moderate and even, to some extent, secularize their political goals and rhetoric, once they are instituted into the system, these transformed religious goals and ideas will continue to have a life and influence of their own. This is especially the case for society-wide faith traditions whose unique

\footnotetext{
${ }^{29}$ Roy, The Failure of Political Islam; Roy, Globalized Islam; The character of this evolution has led several scholars to define Islamist-oriented parties today as post-Islamist parties who have largely abandoned their founding aims; see Asef Bayat, "The Coming of a Post-Islamist Society," Critique 5, no. 9 (Autumn, 1996): 43-52; Olivier Roy, "The Transformation of the Arab World," Journal of Democracy 23, no. 3 (2012): 5-18.

${ }^{30}$ Eva Bellin makes a similar argument about the under-evaluation of religious ideas by rational choice theorists of religion; see Eva Bellin, "Faith in Politics," World Politics 60, no. 2 (2008): 315-47.

${ }^{31}$ Kalyvas, "Unsecular Politics and Religious Mobilization," 309.
} 
combination of organizational resources and spiritual claims sets them apart from most other political interest groups.

While we can certainly fault the essentialist tendency for its over-determinism and static thinking, this strategic-actor model, which inclusion-moderation theorists essentially adopt, also has its limits. One way to recalibrate their handle on religion and politics, while still avoiding the pitfalls of essentialism, is to take an approach that dynamically accounts for the influence of both institutional and ideational factors on religious actors, something along the lines advocated by Philpott, ${ }^{32}$ and again by Toft, Philpott, and Shah..$^{33}$ As these scholars argue, the politics of religious actors can be explained in large part by understanding the interaction between religious actors' political theology and the relationship of religious authority and political authority in a given national setting. ${ }^{34}$

In making this argument, Toft, Philpott, and Shah recognize that religious actors behave as strategic actors and that the institutions governing the relationship between religion and state powerfully frame these actors' goals and strategies. Because religious actors are also strategic actors, the nature of political theology is evolving and dynamic and "continually arrives at new syntheses and consensuses." 35 The authors argue, however, that such acknowledgment does not imply that religious ideas are simply the by-product of non-religious factors. For Toft, Philpott, and Shah, political theology is at once evolving and dynamic, but it is also autonomous, with a particular history and ideational foundation that constrain the actions and goals of religious actors even as those actors reinterpret this past according to new circumstances.

Toft, Philpott, and Shah's approach is useful here because it helps us understand the importance of studying the deep religious backdrop when comparing two religious political parties each with their own history, theology, institutions, and societies. The religious political party, in various ways, is a protagonist of this backdrop and, over time, manipulates, distorts, adds to, and reinvents the backdrop. Critically, however, the religious party is also in conversation with that background and is but one of several of its protagonists. It is for this reason that Toft, Philpott, and Shah emphasize that any study of religious political actors must consider not only religious parties, but also "any individual, group, or organization that espouses religious beliefs and that articulates a reasonably consistent and coherent message about the relationship of religion to politics," ${ }^{36}$ and which may or may not be directly connected to a formal religious

\footnotetext{
${ }^{32}$ Daniel Philpott, "Explaining the Political Ambivalence of Religion," American Political Science Review 101, no. 3 (2007): 505-525.

${ }^{33}$ Toft, Philpott, and Shah, God's Century.

${ }^{34}$ Toft, Philpott, and Shah define this as, "the set of ideas that religious actor holds about what is legitimate political authority," God's Century, 23.

${ }^{35}$ Ibid., 29.

${ }^{36}$ Ibid., 23.
} 
political party or institution. In this broader analytical optic, we have to account for the implications of participation and the institutionalization of religious politics not only on a religious party, but also on religious society, and a society with a clear religious past.

Even as religious political parties may largely secularize in a democratic environment, therefore, Toft, Philpott, and Shah's work reminds us that they remain part of a much larger network of religious-political actors and individuals who might not secularize. The religious ideas and religious identities these individuals profess continue to actively bind their strategic goals in democratic settings. We cannot rule out, for example, that the original religious-political purpose of a religious party may have been somewhat satisfied in the relatively straightforward act of political participation and that this act might have made it easier for a new religious project and synthesis to be carried on by non-party religious actors. Secularization, thus, may only represent one important element of a wider transformation of the relationship between religion and politics, creating new configurations of religious power in society. We will only be able to get an idea of any larger impact of political theology's new syntheses in a democracy by taking a look at the sources and history of that theology in the first place.

From a Toft, Philpott, and Shah perspective, thus, Huntington and the essentialists were not wrong to raise the question of how religion matters as a cultural or civilizational variable and whether religious specificities might affect the response of Catholic and Muslim societies to democratization. This brings us back to the original questions of this paper, namely, what does it matter that Christian Democratic or Islamist inspired parties are religious parties with two different religious pasts? If we want to know whether Muslim Democracies might look different from Christian or Catholic Democracies (and whether either is distinct from secular democracy), we have to know something about the origins of political Catholicism and political Islam and whether the evolution of their political theology sufficiently matches up.

\section{Democratic Encounters: Comparing Islam and Catholicism}

So, to begin with, are Islam and Catholicism even comparable as religions? And which Islam and which Catholicism are we referring to? Social scientists have long debated what exactly needs to go into a definition of religion (and whether it is even a meaningful term of analysis). ${ }^{37}$ There is much disagreement over whether to include any reference to supernatural belief in the definition. In this paper, I employ a definition which includes supernatural belief and argue that we gain important insight into the political goals and resources of religious individuals derived from this belief, as opposed to those

\footnotetext{
37 For a detailed critique of many definitions of religion, including the definition I use here, see William T. Cavanaugh, "If You Render unto God What is God's, What is Left for Caesar?" The Review of Politics 71, no. 04 (2009): 607-619; Robert Bellah's magnum opus, Religion in Human Evolution: From the Paleolithic to the Axial Age (Cambridge, MA: Harvard University Press, 2011), also offers a very useful discussion.
} 
stemming from other ritualistic belief systems that are not oriented as such. For the purposes of this paper, I adopt Appleby's definition of religion, namely that,

Religion is the human response to a reality perceived as sacred...religion, as interpreter of the sacred, discloses and celebrates the transcendent source and significance of human existence...In a common formula: religion embraces a creed, a cult, a code of conduct, and a confessional community ... Thus religion constitutes an integral culture, capable of forming personal and social identity and influencing subsequent experience and behavior in profound ways. ${ }^{38}$

Catholicism, it should be noted here, could be considered as one autonomous variant of a larger creed, cult, code, and community among many pertaining to the religion of Christianity, just as Islam as a religion contains many codes and communities itself, including, importantly, various subdivisions of Sunni or Shi‘a Islam. What is more, within Sunni Islam or even the most hierarchical Roman Catholic Church, Appleby's doctrines and dogmas, disciplines, and worship traditions can vary from one national context to another and, within nations, from one local setting to another, sometimes in contradicting ways. Even as we recognize this rich variety and internal pluralism within either religious tradition, according to Appleby's categorization, we can still compare Islam and Catholicism as faith traditions to the extent that they define a more or less recognized overarching creed, cult, code of conduct, and confessional community.

Islam and Catholicism, however, share further important characteristics as faith traditions, namely, they are transnational, monotheistic, Abrahamic religions. They are also religions whose doctrines of faith aspire to universality and, as such, both Islam and Catholicism share an impetus to proselytize. They are also religions of a "book," that have received, in custody, a revelation of truth that was subsequently written down in a canon of sacred scripture. However, in order to proselytize in a way that is accessible to many cultures, their respective sacred books have needed to be translated and ultimately interpreted in myriad different ways. This universal urge of both religions has led Islamic and Catholic leaders to adapt these narratives over time to local practices, and Muslim and Catholic societies have produced variegated options and complex systems of jurisprudence for organizing the arrangement of religious and political power in specific societal arenas. ${ }^{39}$

This shared status as historical, universalizing religions sets both Catholicism and Islam apart from other universalizing non-religious political ideologies, such as

\footnotetext{
38 R. Scott Appleby, The Ambivalence of the Sacred: Religion, Violence, and Reconciliation (Oxford: Rowman \& Littlefield, 2000), 8.

${ }^{39}$ David D. Laitin, Hegemony and Culture: Politics and Change Among the Yoruba (Chicago: University of Chicago Press, 1986); Khaled A. El Fadl, And God Knows the Soldiers: The Authoritative and Authoritarian in Islamic Discourses (Lanham, MD: University Press of America, 2001).
} 
liberalism, fascism, and communism. While deeply concerned with the bic et nunc, the ultimate goal of both religions is with transcendent, spiritual reality. Their worldly and other-worldly visions do not sit in one-to-one correspondence with a singular political or institutional vision. As long as it is possible to achieve spiritual goals, religious actors are structurally flexible over time, and they need to be characterized as being "multi-vocal" entities. ${ }^{40}$ Reducing religion to a political ideology whose function is to simply rule, coerce, or organize power ignores the avowed spiritual goals and origins of religions as a set of beliefs about the supernatural. Such ignorance constrains our ability to understand the longevity of either Islam or Catholicism and their ability to survive the rise and fall of a number of political ideologies for organizing power over the centuries.

Given their multi-vocal and politically variegated histories, we could trace how the exact political formation and religious organization of both religions evolved throughout the centuries, as did trends in theology, culture, and politics, building up over time a large repertoire of symbolic and ideational resources for either to mine. However, it is equally important to recognize that this political variation was always directed to a certain, more or less fixed, core celestial vision, premised on the written set of revealed truth found in either the Bible or the Qur'an-what Toft, Philpott, and Shah would refer to as either religion's "formative teachings." Over the centuries, religious leaders in both religions, thus, have sought to preserve as well as translate the important values, ethics, and beliefs which are central to the revealed truth of their faith.

Despite either's multi-vocality, the universal urge to share this truth and to protect it also led religious leaders to use their moral and spiritual authority to seek out hegemonic societal status. ${ }^{41}$ With the avowed goal of guarding human society from the evils and corruption of wrong belief, religious leaders attempted to underwrite and direct the order and morality of society, even though doing so meant collaborating intimately with monarchical, authoritarian, and sultanistic regimes. ${ }^{42}$ The morality and order that religious leaders promoted and the divine anointing that they accorded political leaders turned out to be very useful for authoritarian rulers as well, to conquer, unite, subdue, and sustain vast geographic territories. From around 700 to about $1500 \mathrm{AD}$, this alliance of religion and politics consolidated into two distinct religious civilizations, that of Christendom in Catholic Europe and Dar al-Islam in the Islamic Middle East. Kings, princes, popes, and bishops in the Holy Roman Empire and caliphs, sultans, emirs, and

\footnotetext{
${ }^{40}$ Alfred Stepan, The World's Religious Systems and Democracy: Crafting the "Twin Tolerations:" Arguing Comparative Politics (Oxford: Oxford University Press, 2001).

${ }^{41}$ Brown, Religion and State; Gillespie, The Theological Origins of Modernity.

${ }^{42}$ John L. Esposito and John O. Voll, Islam and Democracy (Oxford: Oxford University Press, 1996); Appleby, The Ambivalence of the Sacred; Lovin, Christian Realism and the Nerw Realities.
} 
muftis in the 'Abassid and Ottoman Empires joined forces in a political system which drew on established spiritual truths to define these civilizations' existence and legitimacy. As the animating forces of these civilizational projects, Islam and Catholicism were the unchallenged background ether which provided logic and meaning to social morality and political reality; endorsed a specific ordering of society that was ultimately directed towards God; and mediated the powerful "forces of darkness" in the world. ${ }^{43}$

These ideals of either civilization were not only transnational, but also, crucially, pre-Westphalian. ${ }^{44}$ The idea of either a united Christendom or a Dar al-Islam in which the living body of Christians defined as "the church" or the entire body of Muslims defined as "the Umma" lived their faith protected and unchallenged was not wedded to, nor under the control of, any one national, sovereign state. Even when the rise of the supreme state consolidated its power over religious institutions to a greater (in Protestant and Muslim nations) and lesser (in Catholic nations) degree, ${ }^{45}$ this transnational ideal remained for both Islam and Catholicism. ${ }^{46}$ The Umma residing in Dar al-Islam or the idea of a Catholic Civilization continued to exist in the collective Islamic and Catholic memory and successive political projects were welcome to tap into it for political mobilization.

\section{Theological Hierarchies}

These shared characteristics re-frame the theological differences between Islam and Catholicism that the essentialists focused on, especially with respect to their traditions regarding the separation of religion and state. On the one hand, Huntington et al. are right: since the beginning of Christianity there has been a tradition distinguishing between two distinct spheres of reality, one divine and one secular. What these political scholars missed, however, is that those two spheres were always intrinsically connected to one another and there was a clear order to the two. Augustine does articulate a "city of God" in contradistinction to an earthly one, but the ideal earthly city was meant to draw on the city of God, imitate it, approach it, and submit to its moral ordering as best it could in a fallen world of sin. In Christendom, we can talk about a political versus a spiritual sphere, and some division of labor between them, but these two spheres were united under the authority of one sovereign God and directed towards his purposes.

Some verses from the New Testament, in fact, approach the Qur'anic verses referenced above about God's political status in placing sovereignty squarely with Him

\footnotetext{
${ }^{43}$ R. Scott Appleby, The Ambivalence of the Sacred.

${ }^{44}$ Philpott, "The Religious Roots of Modern International Relations;" Casanova, "Civil Society and Religion."

${ }^{45}$ For excellent discussions on the variation in the rise of the supreme state in Protestant, Muslim, and Catholic nations, see Helmy, "The Historical Process of State Regulation of Religion;" Philip S. Gorski, "Historicizing the Secularization Debate: Church, State, and Society in Late Medieval and Early Modern Europe, Ca. 1300 to 1700," American Sociological Review (2000): 138-167.

${ }^{46}$ Brown, Religion and State; Casanova, "Civil Society and Religion."
} 
alone. In doing so, they bring into question the strict separation of religion and politics that Huntington and others present as an undisputable scriptural fact in Christianity. These include Jesus' response to the Roman procurator Pontius Pilate,

You could have no power at all against me unless it had been given you from above (John 19:10).

And the Apostle Paul's letter to the Romans,

Let every soul be subject to the governing authorities. For there is no authority except from God, and the authorities that exist are appointed by God. Therefore whoever resists the authority resists the ordinance of God and those who resist will bring judgment on themselves (Romans 13:1-2).

This historical socio-political reality radically changes the context for understanding Matthew's verse, one in which God and Caesar have neither equal nor independent roles. On the one hand, therefore, these verses have been long interpreted in certain traditions as a justification for Christian individuals to resist immoral governments. As Cavanaugh points out, in his article titled, "If You Render unto God What is God's, What is Left for Caesar?," the early Christian Church understood Matthew's verse in this manner and resisted the state when it commanded them to act against the moral and social order of their community of religious faith. ${ }^{47}$ Thus, even though they did not explicitly attempt to establish a theological-political order, early Christians were not considered to be ideal citizens and were persecuted and killed for challenging the governmental order of the day when they refused to recognize the political supremacy of the state. ${ }^{48}$

On the other hand, however, the above verses from Romans can also be understood as an exhortation by Paul to encourage obedience to political rulers who do recognize that their authority derives from their function as God's ministers on earth. ${ }^{49} \mathrm{With}$ the advent of Constantine, Caesar became this Christian servant and defender of God's revealed truth on earth and thereby resolved the political dilemma of the early Christian Church which had sometimes pitted them against state authorities. By assuming the duty to enforce the power of judgment over the Christian community, the Christian political ruler transfers the position of authority within the religious community to the

\footnotetext{
${ }^{47}$ Cavanaugh, "If You Render unto God What is God's."

${ }^{48}$ Popular martyrs of the first and second century, for example, were executed for refusing to worship Caesar or his gods (Stephen and the apostles); refusing to fight as soldiers (Marcellus); and refusing to marry non-Christian Roman nobles (Agatha and Lucy).

${ }^{49}$ Often referred to as Paul's theology of state; Perez Zagorin, How the Idea of Religious Toleration Came to the West (New Jersey: Princeton University Press, 2003).
} 
whole political community. Thus, in the person of Constantine, whatever dichotomy was left in Matthew's verse is lost, and giving to Caesar also becomes giving to God, modulating Cavanaugh's observation to: "If you want to give to God what is God's, give everything to Caesar." While Augustine argued that Christians owed higher allegiances to the city of God, like Paul, he recognized that Christians had an active political part to play in the earthly city of men. Augustine's advice on state policies towards non-orthodox Christian believers reveals the extent to which he believed that Christians should appeal to the state to help construct a Christian society. As Zagorin has illustrated, ${ }^{50}$ Augustine came to think that it was theologically advisable for Christian rulers to employ the use of coercive force against the false and dangerous religious ideas proposed by heretics and schismatics. ${ }^{51}$ This defense of coercion contributed to a full-out theology of religious persecution of unbelief which dominated temporal rule in medieval Christendom.

In the Islamic tradition, from the time of Dar al-Islam, we can discern a shared recognition of various spheres of reality and the proper competencies or specializations within those spheres. Yet, we can also distinguish a similar understanding of the hierarchy between those spheres, which, in theory, placed the divine above the material.

Lapidus describes this distinction in the Islamic tradition as a de facto separation of religion and state. ${ }^{52}$ Even in the most idealized days of the Ottoman Caliphate, the Caliph, who held the title of "defender of the faith and ultimate authority of the land," did not make theological pronouncements and rarely ventured into the fields of theology, morality, or ethics. Although they were institutionally de-centralized as a single authority and were often politically weak, this meant that religious authorities in Islam-Muslim legal scholars or 'Ulamä'-enjoyed high symbolic power as guarantors of the divine mandate of the Caliph and the just order of his rule. Like in Christendom, rulers within Dar al-Islam were theoretically beholden to a higher divine power, and their earthly rule was subject to certain obligations and responsibilities to God and his faithful believers. The 'Ulamä"s power is derived from their status as interpreters or judges who determined whether those obligations were being fulfilled..$^{53}$ These responsibilities included the need for ruling in a manner which consulted (shura)

\footnotetext{
${ }^{50}$ Ibid., 28ff.

${ }^{51}$ Writing to the Roman governor of Africa in $417 \mathrm{CE}$ that, "There is an unjust persecution which the wicked inflict on the Church of Christ, and... a just persecution which the Church of Christ inflicts on the wicked," as quoted in Zagorin, How the Idea of Religious Toleration Came to the West, 30.

52 Ira M. Lapidus, "The Separation of State and Religion in the Development of Early Islamic Society," International Journal of Middle East Studies 6, no. 4 (1975): 363-85; see also Brown, Religion and State; and Mohammed Ayoob, The Many Faces of Political Islam: Religion and Politics in the Muslim World (Ann Arbor, MI: University of Michigan Press, 2007).

${ }^{53}$ Abdullahi A. An-Na'im, Islam and the Secular State: Negotiating the Future of Sharia (Cambridge, MA: Harvard University Press, 2008).
} 
and found consensus (ijma) among the people by ruling justly, providing certain social rights, and guaranteeing the protection of strangers and non-Muslims. ${ }^{54}$ The existence of these responsibilities created some basis for a social contract between ruler and ruled, as well as some check on the ruler's political power. While affirming the virtue of public order, these divinely mandated responsibilities also provided resources which many scholars have argued could be used to justify democratic reforms. ${ }^{55}$

As in the case of Christendom, the 'Ulam $\vec{a}^{\prime}$ often simply rubber-stamped political projects, but, Lapidus notes, ${ }^{56}$ the ideal of the 'Ulama "s right to contest unjust political power remained and, especially in earlier times, was occasionally seized upon to protest or revolt against unpopular regimes. Ibn Khaldun's famous theory of urbanrural cycles of reform illustrates this tradition well. He argued that rural reformers, animated by religious purity and justice, periodically overthrow urban, cosmopolitan, elite rulers who become corrupt, lazy, and out of touch over time. Ibn Khaldun's theory acknowledges the expectation of religious authority to challenge unjust political rule as well as the necessity for material power to remain subject to higher spiritual laws in order to rule effectively, thus requiring the occasional purification. ${ }^{57}$

The potential of the 'Ulam $\bar{a}$ ' to challenge political power was increased by their authority in society. As Eisenstadt notes, ${ }^{58}$ the 'Ulama $\bar{a}^{\prime}$, in their function as interpreters of Qur'anic law, had immense power over the interaction of relationships and mores in society, and people turned to them for guidance and advice in all matters of everyday life. Traditionally, the Sultan or Caliph allowed the 'Ulamä' this independence and profited from the ability of their religious authorities to keep the social peace. In Shi'a Islam where this authority is even more institutionalized, the clergy's independence and potential for contestation was even greater..$^{59}$ Eisenstadt goes so far as to describe the 'Ulam $\bar{a}$ ' as the keepers of the public sphere in Islamic societies, making them one of the only sources of authority independent of state rule. ${ }^{60}$ This created an alternative

\footnotetext{
${ }^{54}$ The Qur'anic verses from Al-Baqarah, 2:256, "There is no compulsion in matter of faith," and Al-Ghashiyah, 88: 23, "Thou hast no authority to compel them," are often used to justify such protection. Mohammed Charfi, Islam Et Liberté. [Islam and Freedom] (Algiers: Casbah Editions, 2000), 162; also points to Yunus, 10: 100, "And if thy Lord had enforced His will, surely, all who are on the earth would have believed together. Wilt thou, then, force men to become believers?"

${ }^{55}$ Addi, L'Algérie Et La Démocratie; Esposito and Voll, Islam and Democracy; Charfi, Islam Et Liberté; Azzam S. Tamimi, Rachid Ghannouchi: A Democrat Within Islamism (Oxford: Oxford University Press, 2001).

${ }^{56}$ Lapidus, “The Separation of State and Religion in the Development of Early Islamic Society;” Ira M. Lapidus, A History of Islamic Societies, vol. 2 (Cambridge: Cambridge University Press, 1988).

${ }^{57}$ Shmuel N. Eisenstadt, "Multiple Modernities," Daedalus (2000): 1-29.

${ }^{58}$ Ibid.

${ }^{59}$ Gilles Kepel, The Revenge of God: The Resurgence of Islam, Christianity, and Judaism in the Modern World (University Park, PA: Pennsylvania State University Press, 1994).

${ }^{60}$ Ibid.; See also, Dale F. Eickelman and Armando Salvatore, "Public Islam," Etnográfica 10, no. 1 (2006): 97-105; Shmuel N. Eisenstadt, Comparative Civilizations and Multiple Modernities, vol. 1 (Leiden: Brill, 2003).
} 
set of allegiances for citizens and increased the potential of the 'Ulam $\bar{a}$ ' to mobilize and challenge the authority of the state. It also insured the primacy of the divine sphere over the material as well as the 'Ulam $\bar{a}$ "s authority as guardians and interpreters of the revealed truth.

Therefore, while the tradition may have been less theologically articulated in Islam, ${ }^{61}$ we can agree with Lapidus that,

Though the modalities of "state" and "religion" in the Islamic world are quite different from those of "state" and "church" in the West, Islamic society, in fact, if not in its own theory, is one of those societies in which religious and political institutions are separate..$^{62}$

In this light, as many other scholars have argued, ${ }^{63}$ Islamist proposals that call for a totalizing Islamic state represent an anachronistic break with traditional Muslim politics in which the 'Ulam $\bar{a}^{\prime}$ work together with, but remain autonomous of, Muslim princes.

Yet, we can also conclude that in Dar al-Islam, as in Christendom, this separation had a clear order to it in which religious authority (and not the state) represented the ideologically non-neutral final arbiter over the moral economy and political discourse of society. As Frégosi writes, ${ }^{64}$ despite their historical differences and despite the birth of Luther, in this respect, it is nearly impossible to compare Islam and Catholicism between the years 700 and 1500 and argue that one was more disposed than the other to generating democratic institutions and ideas. For both Catholicism and Islam, the timing and pace of substantive liberal reform appeared as a frontal assault on centuries of political theology that had advocated that the state ensure religious orthodoxy, promote the regeneration of religious truth, and bow to a moral ordering mandated by God and preserved by religious authorities. In the words of Marty and Appleby, ${ }^{65}$ this led to striking "family resemblances" in the types of theological arguments that Catholic and Muslim leaders have selected from their traditions to support that hostility. Equally important, however, these reactions should not make us forget the alternative resources either Islam or Catholicism had at its disposition

\footnotetext{
${ }^{61}$ Brown, Religion and State.

${ }^{62}$ As quoted in Esposito and Voll, Islam and Democracy, 95.

${ }^{63}$ Roy, Globalized Islam; Addi, L'Algérie Et La Démocratie; Hashemi, Islam, Secularism, and Liberal Democracy.

${ }^{64}$ Franck Frégosi, "Les Rapports Entre L'islam Et l'État En Algérie Et En Tunisie: De Leur Revalorisation à Leur Contestation" [Relationships between Islam and state in Algeria and Tunisia: From revaluation to contestation], Annuaire De l'Afrique Du Nord 34 (1995): 103-123.

${ }^{65}$ R. Scott Appleby and Martin E. Marty, eds., Fundamentalisms Comprehended (Chicago: University of Chicago Press, 1995).
} 
to contest authoritarian politics-whether the early years of the Catholic Church and its institutional articulation of distinct spheres or Islamic traditions of consensus, consultation, non-compulsion, and equality. ${ }^{66}$

\section{What about Protestants and Democracy?}

As mentioned above, scholars have long recognized a special historical relationship between the Protestant Reformation and the rise of the democratic nation-state in the West. A brief consideration of the relationship between Protestantism and democracy helps us understand what is essentially similar about the hostile reactions of Catholic and Muslim leaders to early liberal democratic reform. At the same time, it gives us a clearer picture of the resources that both Catholicism and Islam share in common with Protestantism which helped create the possibility of democracy in the Protestant West.

The first thing to emphasize is that the Protestant Reformation did not immediately produce democratic flourishing. The original aim of Luther and other reformers was to make religious faith more purely and wholly guiding of humans' lives, not less. The cycle of puritanism and radical reformation which followed in the wake of Luther spawned Calvin's 1500 s caesaropapist regime of Geneva, ${ }^{67}$ which inflicted severe punishments on any citizen who broke the moral code Calvin had instituted, long before it influenced the origins of the United States. The radical energy, however, with which puritans went about attacking traditional religious structures, could be understood to be proto-modern. ${ }^{68}$ Thoroughly questioning the authority of extant religious institutions and doctrines legitimized, in the long run, a similar questioning of the whole endeavor of societal religious belief itself. ${ }^{69}$

\footnotetext{
${ }^{66}$ As Charfi writes in this respect, "Since the century of the Enlightenment, the combat for liberty was directed against the monarchy in its representation of authoritarian state and divine law, two notions which were intimately connected. Democracy could not truly install itself durably in Europe until after the affirmation and application of the neutrality of the state towards religion. The Church resisted such things as much as it could in this evolution until it then accepted them. At such a point, Christian thinkers found this old principle within their patrimony, that it was necessary to give to Caesar what was Caesar's and to God what is God's, a principle which was forgotten for many long years but today is quite welcome. Muslim theologians cannot find such a principle from within our patrimony because circumstances have not favored its emergence," Islam Et Liberté, 188; Hashemi makes a similar point in Islam, Secularism, and Liberal Democracy.

${ }^{67}$ Calvin's Geneva serves as Juan Linz's classic example of caesaropapist authoritarianism in "Totalitarianism and Authoritarianism," in Handbook of Political Science, vol. 3: Macropolitical Theory, ed. Fred I. Greenstein and Nelson W. Polsby, Reading, MA: Addison-Wesley, 1975.

${ }^{68}$ What Michael Walzer called the "revolution of the saints" in The Revolution of the Saints: A Study in the Origins of Radical Politics (Cambridge, MA: Harvard University Press, 1982); see also Gorski, The Disciplinary Revolution; and Hashemi, Islam, Secularism, and Liberal Democracy.

${ }^{69}$ Charles Taylor's work describes this process in the West very well in A Secular Age (Cambridge: Cambridge University Press, 2007). On this point, scholars have noted a similarity between radical reformation politics in sixteenth century Europe and recent versions of radical Islamism. In either case, the drive to purify religion of its historical and cultural settings led to a greater fragmentation of religious authority in politics and society; see Roy, Globalized Islam; Olivier Roy, Holy Ignorance: When Religion and Culture Part Ways (New York: Columbia University Press, 2010); Hashemi, Islam, Secularism, and Liberal Democracy.
} 
The reformation, thus, created a certain congruence between the goals of both religious and political elites and their desire to break up the traditional relationship between political and religious authority, ${ }^{70}$ even as this goal had the unintended, longterm consequence of diminishing religious authority and belief in society as a whole. ${ }^{71}$ Such separation helped religious leaders to shift the focus of devotion from public acts of religious conformity to the pursuit of personal salvation, and to insulate themselves from the temptation of corruption and excess by which the Catholic Church had forsaken its divine mandate for a political-material one. However, the same separation also allowed political authorities to break all political responsibilities with the popes in Rome, which had hitherto blocked the consolidation of state power away from religious power, as noted above. Later, as liberal ideas and democratic institutions evolved in Protestant Europe, this congruence meant that the separation of religion and state required to institute the authority of elected officials over liberal political regimes was a matter of degree, not fact. It did not entail a dis-establishment of religion, but, rather, a proper separation of those spheres.

I want to re-emphasize here this intimate connection between the birth of Protestantism and the modern system of nation-states that more fully separated the spheres of church and state. As Philpott writes, "sovereignty was implied in the very propositions of the Reformation." 72 Many reformed Protestant leaders would later resist liberal political change that tolerated heretical versions of religious belief and other forms of religious pluralism, like their Catholic and Muslim counterparts did. The Protestant Reformation, however, had already severed the cord binding the state to religious authority. By rejecting the idea of a politically united Christian civilization in favor of nationally defined territories, the Reformation brought into question the entire relationship between state and religion and the responsibilities of temporal rulers to God. As Hashemi writes, ${ }^{73}$ when Locke argued, on religious grounds, for religious tolerance and the separation of church and state authority in seventeenth century England, he already assumed that the state had the supreme right to regulate its religions. In Protestant countries, therefore, liberal reform was not framed as an attack on a thousand years of political theology, but as the appropriate shaping of a new political religious tradition which explicitly recognized the desirability of some distance for religious leaders from political functions. This was not the case for the Catholic countries of Europe where the Church did not recognize the supremacy of the state as such. Liberal reforms in Catholic countries required, a priori, dislodging

\footnotetext{
70 This congruence is what Kuru terms ideational and institutional bridges; Philpott, "The Religious Roots of Modern International Relations;" Lovin, Christian Realism; Gillespie, The Theological Origins of Modernity.

${ }^{71}$ Minkenberg, "Democracy and Religion.”

72 Philpott, “The Religious Roots of Modern International Relations,” 223.

${ }^{73}$ Hashemi, Islam, Secularism, and Liberal Democracy.
} 
the international power of the Catholic Church over the state, making liberal projects synonymous with the dis-establishment of a national faith tradition. The relationship between proponents of democracy and the leadership of the Catholic Church was, consequently, more antagonistic and mutually exclusive.

In this respect, important parallels can be made regarding the experiences of Catholicism and Islam. Neither the rise of the supreme state in the fifteenth century Ottoman Empire, nor the rise of Islamism as a political ideology threatened the state's sponsorship of religious authority as had long been accepted in Dar al-Islam. ${ }^{74}$ As a result, neither ignited a spiral of increasingly secular ideas about the relationship between religion, state, and society as the Protestant Reformation did. ${ }^{75}$ This is an important difference to point out with respect to Islamism. Both Islamist and Protestant reformers sought to recreate a purified religious society and in doing so, Islamists, like Protestant reformers, broke with traditional religious authorities of the day, creating splits over the locus of legitimate religious authority in Muslim nations. However, while Luther emphasized that spiritual decline in Europe was a function of the temporal political power accumulated by Catholic religious authorities, Qutb, Mawdudi, and others proposed that the decline of Muslim society had to do with the dissociation of religious authority from politics. The Islamist solution, therefore, was not to hand over coercive force to a secular prince charged with defending a national faith, as the Protestant Reformation did, but to invest religious authorities themselves with that coercive power.

In this optic, Islamism can be understood as a reaction to the radical challenge to religious authority that came first through colonialism and then through Arab national regimes. The colonial conquest of much of North Africa and the Middle East, particularly by France and Great Britain, brought non-Muslim foreigners to rule over much of Dar al-Islam for the first time in more than five hundred years. The state establishment of Islam meant that colonial rulers not only ruled over local politics, but also over national religious institutions. French authorities in Algeria, for example, after conquering the country, took control of the Algerian religious establishment, including its buildings and finances, and managed both of them poorly. ${ }^{76} \mathrm{It}$ is little wonder that early Algerian attempts at colonial resistance began when Algerian religious leaders, such as Ibn Badis, mobilized to reclaim their religious and cultural independence from the French. While many religious elites initially joined the first independent Algerian government, when it became clear that the program of the secular Arab elites in power was to forcibly sideline them, they began mobilizing against the state. The

\footnotetext{
${ }^{74}$ Helmy, "The Historical Process of State Regulation of Religion and its Democratic Implications."

${ }^{75}$ Nader Hashemi, "The Multiple Histories of Secularism Muslim Societies in Comparison," Philosophy E Social Criticism 36, no. 3-4 (2010): 325-338.

${ }^{76}$ Driessen, "Public Religion, Democracy, and Islam." 
original political grievance of Islamism, therefore, was that religious authority had been manipulated and marginalized by non-Muslim colonial rulers and strong-armed secular elites. Accordingly, the initial impulse of the Islamists was to restore and purify the religious authority of the state. The replacement of secular political elites was their target, not religious political elites as was the case for Protestant reformers living under Catholic Christendom.

In the experiences of both Catholicism and Islam, we can now see that what is at stake is not so much the technical differentiation of religious and political functions in the state, per se, which has precedent in both traditions. Rather, what is at issue is the way in which political differentiation came to Muslim and Catholic societies and its explicit top-down challenge to religious authority and the ideals inherited from an integral transnational civilization. The religious and political mobilization generated by political Islam and political Catholicism, responded to the perception that the religious nature of state and society was under threat. ${ }^{77}$ Critically, given the timing and results of the Protestant Reformation, religious claims over state sovereignty were largely a settled issue in Protestant countries before the advent of mass-based politics in northern Europe ${ }^{78}$ As noted earlier, the Catholic Church resisted this secularization of the state much longer and was able to channel that resistance into society-wide confessional parties. In Islam, the threat to religious authority came later and religious leaders were likewise able to transform popular political resentment into a massive political religious movement.

\section{Catholic and Muslim Modernities/Civilizational Forces: Pius XII and Ghannouchi}

So far I have described a similar deep historical and theological backdrop animating the rise of political Catholicism and political Islam. This backdrop simultaneously fueled the original hostility of Muslim and Catholic political movements toward democracy, but also endowed them with the ideational breadth and flexibility to recraft their vision of democracy as they faced new institutional environments. Despite all their differences, we can now more confidently say that Islam and Catholicism can be meaningfully compared, both as religions and with respect to their experiences with democratization. As scholars attempt to understand the behavior of Islamist-inspired political parties in the Middle East and North Africa today, it does make sense to take a comparative look at the project of Christian Democracy, not only with respect to the patterns of practice and behavior of Christian Democratic parties, but also with respect to the ideas about democracy that they championed.

\footnotetext{
${ }^{77}$ Altinordu, "The Politicization of Religion;" Kalyvas, "Unsecular Politics and Religious Mobilization."

78 This does not imply that there was no anticlericalism in Protestant countries, see, among others, Lipset and Rokkan's description of the party effects of church-state tensions in the Netherlands, but, for these reasons, I argue it was simply not the same order of scale as in Catholic countries; see Seymour M. Lipset and Stein Rokkan, Party Systems and Voter Alignments: Cross-national Perspectives, vol. 7 (New York: Free Press, 1967).
} 
Following the theoretical framework developed in the first section of this paper, I would like to suggest that the articulation of this background theology also helps us to think about how the religious intuitions buried in these pasts might project forward in religious democracies in a way that is not at odds with the observation of secularization/moderation on the part of Christian Democracy and Islamist-inspired parties. The observation of secularization, in fact, could be read in part as the result of a new realization, namely that the foundational project of constructing an authentic religious society can still be pursued, perhaps pursued in a better manner, ${ }^{79}$ with a more explicit separation of spheres in those political contexts that allow or even encourage the public presence of religious political movements and values.

The regeneration or reinvention of a Muslim or Catholic society with a specific religious reference and past is a useful way to think about how the legacy of Christendom or Dar al-Islam might translate into new democratic settings. As an example of what I am demonstrating, I would like to point to the attempt of religious leaders, who have accepted democracy as a legitimate political framework, to establish religion as the social and spiritual institution that makes democracy work. "Muslim, or Catholic, modernities" is the term scholars might use to describe the alternative trajectories these religious democracies might take. ${ }^{80}$ Catholic and Muslim religious leaders themselves, however, often refer to this project as promoting Islam or Catholicism as a "civilizational" force. Two similar conceptions of this requirement for Muslim or Catholic civilization to fill a healthy democracy can be seen in Pope Pius XII and Rachid Ghannouchi's pioneering tracts on democracy. ${ }^{81}$

Towards the end of the Second World War, Pope Pius XII (1938-1958) developed an understanding of the Church's role in politics as that of Defensor Civitatis. ${ }^{82}$ Commenting in his 1944 Christmas Radio Message, he noted that, ${ }^{83}$

If the future belongs to democracy, an essential part in its achievement will have to belong to the religion of Christ and to the Church, the messenger of our Redeemer's word which is to continue His mission of saving men.

\footnotetext{
${ }^{79}$ As An-Na'im writes in the first lines of his book, "In order to be a Muslim by conviction and free choice, which is the only way one can be a Muslim, I need a secular state;" see An-Na'im, Islam and the Secular State, 1.

${ }^{80}$ Eisenstadt, "Multiple Modernities."

${ }^{81}$ Ghannouchi is a pioneer in the sense that he has often been described as the first Islamist to formally endorse democracy, and Pius XII is the first pope to do so as well; see Burgat and Dowell, The Islamic Movement in North Africa; Leicester Chisholm Webb, Church and State in Italy, 1947-1957 (Melbourne: Melbourne University Press, 1958).

82 Andrea Riccardi, Il "Partito Romano" Nel Secondo Dopoguerra, 1945-1954 [The "Roman Party" in the second post-war period, 1945-1954], (Brescia: Morcelliana, 1983).

${ }^{83}$ Many date Pope Pius XII's 1944 Christmas Message as the formal acquiescence of the Catholic Church to democracy as a regime type.
} 
For she teaches and defends supernatural truths and communicates the supernatural helps of grace in order to actuate the divinely-established order of beings and ends which is the ultimate foundation and directive norm of every democracy ... The Church has the mission to announce to the world, which is looking for better and more perfect forms of democracy, the highest and most needed message that there can be: the dignity of man, the call to be sons of God. ${ }^{84}$

Echoing Pius XII, Ghannouchi writes that, ${ }^{85}$ "the only way to accede to modernity is by our own path, that which has been traced for us by our religion, our history and our civilization." ${ }^{\prime 66}$ In his book on democracy and Islam, Ghannouchi states that he had realized, ${ }^{87}$ after viewing democracy with suspicion for some years, that

democratic mechanisms have proven to be the best means for Islamic values to be transformed from a set of lofty ideals to practical solutions applicable to living realities. Similarly and for optimum viability, the democratic system will find no better values and no better philosophy, than those offered by Islam. ${ }^{88}$

The realization of Ghannouchi is the realization of Pius XII, which is that democracy is not fundamentally an ideology in opposition to Islam or Catholicism, but rather a set of rules whose meaning can only be made good or bad for human beings according to the quality of its underlying values and the behavior of its people. For either figure, therefore, the success of democracy can only occur if democratic society subdues itself to the values and ideas of Catholic or Muslim thought. This realization represents a clear break from the earlier Catholic or Islamist insistence on the creation of some sort of Islamic or Catholic authoritarian state. At the same time, we can also recognize a strong continuity in this discourse, especially on the role of religious authority in society, to that formulated in Christendom or Dar al-Islam. In the development of their thinking, both draw on a classic formulation of faith and

\footnotetext{
${ }^{84}$ Pope Pius XII, "Democracy and a Lasting Peace," December 25, 1944.

${ }^{85}$ Ghannouchi has made the comparison between political Islam and political Catholicism, saying, "The democratic system has worked within the framework of Christian values, giving rise to Christian democracies and within the framework of socialist philosophy giving rise to socialist democracies. Why on earth should it not function within the framework of Islamic values to produce Islamic democracy?," as cited in Tamimi, Rachid Ghannoucbi, 24.

${ }^{86}$ As cited in Burgat and Dowell, The Islamic Movement in North Africa, 63.

${ }^{87}$ Rachid Ghannouchi, Al-Hurrìyàt Al-ämmah Fìd Al-dawlah al-Islāmìyyah [Public liberties in the Islamic state] (Beirut: Markaz Dirāsāt al-Waḥdah al-'Arabīyah, 1993).

${ }^{88}$ As paraphrased by Tamimi, Rachid Ghannouchi,104.
} 
reason in which reason imposes the institution of democracy as the best contemporary form of government, but that, simultaneously, good democratic practices only become possible when that democracy is lived and crafted in the light of faith. Pope Pius XII writes in this respect,

As they are established on this same foundation, the person, the state, the government, with their respective rights are so bound together that they stand or fall together. And since that absolute order, in the light of right reason, and in particular of the Christian Faith, cannot have any other origin than in a personal God, our Creator, it follows that the dignity of man is the dignity of the moral community willed by God, the dignity of political authority is the dignity deriving from its sharing in the authority of God ${ }^{89}$

And Ghannouchi,

This dialogue between reason and revelation on the one hand, and revelation and reality on the other, is essential to the life of both reason and religion. Revelation's relation to reason is like that of the eye to light—as expressed by Abu Hamid al-Ghazali. Neither may exist without the other. Such is Islamic rationality; it has as its foundation stone the principle of recognition of the dualism of reason and revelation and the insistence upon the need of each for the other, for mutual rejuvenation..$^{90}$

Even as democracy is accepted as a legitimate political regime, therefore, it is also accepted as the most reasonable framework of the moment to continue the project of Catholic or Muslim civilization. The actual, final shape of this religious-democratic project, naturally, does not depend simply on the idea of it as articulated by major religious political thinkers; in large part, its final shape will be determined by the strategic political actions and practices of religious-political actors from the religious party and beyond. However, through Pius XII and Ghannouchi, we begin to see a synthesis emerging about the old religious intuition of religious society, civilization, and culture, which steadies politics by pointing them to a higher, other-worldly reality. As the synthesis emerges, it becomes a possibility to pursue in a democratic framework, and religious political parties, even as they secularize, propel the idea of religious society forward.

\footnotetext{
${ }^{89}$ Pius XII, "Democracy and a Lasting Peace."

${ }^{90}$ As cited in Tamimi, Rachid Ghannouchi, 31.
} 


\section{Conclusion}

In this paper, I have argued that despite differences in theological doctrines, historical experiences, and the timing of either Catholicism or Islam's encounter with liberal democracy, the causes and nature of Islamic and Catholic hostility to democracy are similar. Both faith traditions have overriding ontological similarities as universalizing religions and as the historical guardians of pre-Westphalian, transnational religiouspolitical orders. For a long time, the similar religious ideas found in this deep backdrop, and the way those were framed by historical experiences, made it difficult for Catholic or Muslim Democracies to appear, although it did not exclude their appearance. As the experience of Christian Democratic or Islamist-inspired parties have now made Catholic or Muslim Democracy possible, they carry forward many aspects of this religious legacy. As such, the comparison is a warranted one, and studying these democracies in a comparative light will allow scholars to understand how the interaction of political praxis and political theology will affect their future shape and quality.

It is important to point out, however, that the comparison of political Islam and political Catholicism is not an exact one, and I do not want to imply that an exclusive similarity exists between Islam and Catholicism on all analytical dimensions. As seen in the sections above, there are also compelling theological and political reasons for showcasing similarities between Islam and Protestantism and either's historical relationship to democracy. What is more, historical, institutional, and national contingencies within Catholic and Muslim countries create divergences over time between the two which will prize certain religious responses to similar political situations over others. These contingencies help explain the variations in the ways that new religious projects have been (and will be) pursued and the shape of how they have been (and will be) implemented. As a conclusion, I would like to recommend a future research agenda for the comparison of Christian and Muslim democracies which explores these divergences. Having established that the comparison of the two experiences is valid, and having articulated a similar religious vision of democracy found in either tradition, a forward analysis of the comparison requires that scholars consider how these similarities will refract differently over time. I would like to suggest that one of the most celebrated differences between Islam and Catholicism, namely the centralized structure of religious authority in Catholicism as opposed to the decentralized structure of religious authority in Islam, represents the most logical place to begin this inquiry.

It should be noted that scholars like Kalyvas had previously wondered whether these institutional differences made it more difficult for state authorities to clearly 
negotiate with Muslim actors as opposed to Catholic actors. ${ }^{91}$ Kalyvas, working from the cases of Algeria and Belgium, argued that it was not evident who had credible authority in Islam and who, therefore, was capable of negotiating political deals with state leaders as well as delivering on them. ${ }^{92}$ Due to the institutionalization of rank and authority in Catholicism, it was clear that once a state had made a deal with the pope, the pope's bishops and faithful would most likely rally around that decision.

While it is incorrect to say that there is no hierarchy of religious authority in Islam, the body of authority which pushes forward the religious tradition of a country is more disperse in Islam than Catholicism, and even more disperse in Sunni as opposed to Shi'a Islam. ${ }^{93}$ As Schwedler and Brownlee point out, however, the decentralization of religious authority in Islam seems to have had only an ambiguous effect on the overall likelihood that a state leader might initiate a process of democratization in either a Catholic or Muslim society. ${ }^{94}$ In part, this is because Kalyvas' observation is a sword that cuts both ways. Even while the decentralization of authority in Islam makes negotiations messier, involving more personalities and ideas, the same decentralization of authority also makes it easier for Islamic leaders to negotiate with political leaders and to adapt to new political environments in the first place. Theoretically, the lack of centralized authority in Islam, as was true for Protestantism, makes it easier for Islamic societies to support a greater pluralism of ideas and allow new ideas to ascend in importance more quickly. This also makes it theoretically easier for rulers in Muslim states to co-opt some religious authorities while isolating or even imprisoning others, making Islamic authority structures easier for a state to deal with or manage in the short-run. ${ }^{95}$

The rigid centralization of authority in Catholicism, on the other hand, made it easier for one pontiff to remain personally obdurate to new political propositions over greater lengths of time. Even if the Church's faithful did its bidding more quickly than in Islam, that obduracy also meant that the Catholic Church remained stubbornly opposed to democratic principles even after nominally accepting them. The rigid centralization of ecclesiastic authority might have made it clearer who was at

\footnotetext{
${ }^{91}$ Without questioning the premise that Islam had historical and theological affinities with democracy; Kalyvas, "Commitment Problems in Emerging Democracies."

${ }^{92}$ Ibid.

${ }^{93}$ Brown, Religion and State; Ayoob, The Many Faces of Political Islam. For this reason, authors like Kepel argue that the Shi'a clerical structure makes clear and direct conflict between state and clergy more likely in predominantly Shi' a than Sunni nations; see Kepel, The Revenge of God.

94 Schwedler, "Can Islamists Become Moderates?;” Jason Brownlee, "Unrequited Moderation: Credible Commitments and State Repression in Egypt," Studies in Comparative International Development 45, no. 4 (2010): 468-489.

95 See, for example, Ellen Lust-Okar, "Divided They Rule: The Management and Manipulation of Political Opposition," Comparative Politics (2004): 159-179.
} 
the negotiating table with political forces, therefore, but it also made such authority structures more resilient to change and evolution. It is important to remember here, as noted earlier, that the vertical societal relationships that Catholicism's centralized system of authority encouraged also meant that there was less congruency between societal norms of interaction (or lack thereof) and democratic virtues of egalitarianism, mutual trust, and association. ${ }^{96}$ Once again, theoretically, the structures of authority in Islam, in this sense, would seem to more favorably dispose Islamic societies towards such democratic affinities.

Once they have democratized, however, these institutional differences will certainly affect the shape of Catholic as opposed to Muslim Democracies. One manifestation of these differences might occur in the new configuration of religious authority in Catholic as opposed to Muslim Democratic societies. As in the previous discussion of Pius XII and Ghannouchi, traditionally Catholic configurations of religious power might incise differently than Muslim configurations of religious power on a democracy. In the quote about democracy above, Pius XII expressly hopes not just that the "religion of Christ" would take an essential role in democratic life, but, equally, that the "Church, the messenger of our Redeemer's word" would. ${ }^{97}$ This can be opposed to Ghannouchi's understanding of religious authority in Islam, that sees the decentralization of Islamic religious power as one of Islam's most democratic aspects, making it more amenable to a pluralism of ideas and voices. In contrast to the institution of a Church in Christianity, Ghannouchi writes that,

No such religion-monopolizing paradise-selling establishment exists in Islam whereby religion is turned into a natural authority before which the people lose all power and afford to do nothing but submit to its monopoly of understanding and interpreting religious text, and to its imposed code of prohibitions. $^{98}$

One of the immediate effects of this difference, purely on the level of politics, is the participation of more than one Muslim political party in most Muslim Democracies today, as in the Freedom and Justice Party and al-Nour in Egypt, Ennahda and Hizb ut-Tahrir in Tunisia, and the Movement for Society and Peace and al-Islah in Algeria. Unlike in Catholic Democracies, there is no accepted, hierarchical, papal authority

\footnotetext{
${ }^{96}$ Almond and Verba, The Civic Culture; Putnam, Making Democracy Work.

${ }^{97}$ Immediately after this line, Pius XII points out, "By her very existence, the Church rises before the world as a shining beacon to remind it constantly of that Divine order. Her history reflects clearly her providential mission. The struggles, which coerced by the abuse of power, she has had to sustain in defense of the liberty given her by God, were at the same time struggles for man's true liberty," Pius XII, "Democracy and a Lasting Peace."

${ }^{98}$ As cited in Tamimi, Rachid Ghannouchi, 138.
} 
preventing the emergence of divergent and divisive religious political formations in the Middle East today. We could recognize, therefore, that Muslim Democracy is forced to deal with this question of pluralism much earlier on in the life cycle of its party system than Christian Democracy. Given the way religious authority is institutionalized in Islam, its historical tradition already has proto-institutional ways of dealing with pluralism. Many of the Islamic Councils instituted under the Colonial period, for example, brought together, in a democratic fashion of sorts, religious leaders from various parts to discuss and come to some kind of consensus on the direction of religious authority in the country. ${ }^{99}$ Islamist-oriented parties have access to this legacy today and, therefore, possess early models of how to encourage a religious vision that aims at shoring up the religious nature of society in a way that does not force a monolithic religious identity or authority. In the end, such a monopoly on religious authority is more antithetical to Islam anyway: the unity of the Umma is not, in theory, correlated to any hierarchy of religious authority in Islam.

Despite this legacy, the historical propensity for an established religious institution in Muslim societies signifies that any religious privileges accorded to a Muslim Democracy accrue directly to the state. Because it appoints the official Muslim clergy, pays their salary, and oversees their education, an officially Islamic state, even a democratic one, retains a direct voice over the political and moral goals of official Islam. In the ideal religion-state arrangement of a Catholic democracy, conversely, the hierarchical and independent nature of the Catholic Church signifies that any legal privileges, favors, or symbolic authority accorded to Catholicism accrue directly to the institutional Church's hierarchy, not to a Christian Democratic party or the state. While in the ideal Catholic religion-state setting, therefore, an independent religious organization directs and manipulates its own religious privileges. In the ideal Islamic religion-state setting, the religious organization remains more explicitly regulated by the state.

In Catholic democratic settings, this religion-state arrangement has made it easier for the Church to take on a public religious role that is independent of both the state's bureaucratic regulations and the religious party's fortunes and failures. ${ }^{100} \mathrm{It}$ is unclear whether something similar might happen over time in the case of Muslim Democracies and whether any corresponding public Islam will likewise emerge independent of the religious party or state. ${ }^{101}$ The very definition of what constitutes

\footnotetext{
${ }^{99}$ Luc-Willy Deheuvels, Islam Et Pensée Contemporaine En Algérie: La Revue Al-Aṣâla (1971-1981) [Islam and contemporary thought in Algeria: The Al-Asâla review], (Éd. du CNRS, 1991).

${ }^{100}$ José Casanova, Public Religions in the Modern World (Chicago: University of Chicago Press, 1994).

${ }^{101}$ On public Islam in the plural see Lara Deeb, An Enchanted Modern: Gender and Public Piety in Shii Lebanon (New Jersey: Princeton University Press, 2008); Robert W. Hefner, Civil Islam: Muslims and Democratization in Indonesia (New Jersey: Princeton University Press, 2011).
} 
legitimate religious authority at the inception of Muslim Democracies already appears to be a more contested issue than it was in Catholic Democracies. ${ }^{102}$ In Morocco, Jordan, Egypt, Tunisia, and Algeria, over the past few years, scholars have documented how the state and religious parties have battled to appropriate the shape of future Islam through the office of the ministry of religious affairs and how the politicization of this office has risked catapulting these states back into authoritarianism and religious polarization. ${ }^{103} \mathrm{~A}$ defining feature of new Muslim Democracies, therefore, will likely be this struggle to articulate the new composition of Muslim religious authority, with the goals and policies of the state, party, and religious institutions and movements all adding to its definition. If Islamist-inspired parties and Muslim polities do, indeed, secularize as they internalize democratic ideas and practices, then the state's claims to religious authority might ultimately prove to be a moot source of tension. If, however, society remains religiously-charged and the state is seen to be manipulating its religious privileges for its own ends, it might create new forms of religious conflict between the ideas and goals of various religious actors and those of the guardians of the regime. Understanding these emerging patterns of religious power in society will go a long way to helping scholars in their analysis of the future of religious politics in a more democratic Middle East and North Africa.

\footnotetext{
102 This is not to imply that conflict over authority in the Catholic Church do not exist.

103 Malika Zeghal, Islamism in Morocco: Religion, Authoritarianism, and Electoral Politics, trans., George Holoch (Princeton: Markus Wiener Publishers, 2008); Driessen, "Public Religion, Democracy, and Islam;"Nathan Brown, "Dangers Ahead for Egypt," Op-Ed, Carnegie Endowment for International Peace, May 31, 2012. http://www. carnegieendowment.org/2012/05/31/dangers-ahead-for-egypt/b0xx; Maaike Voorhoeve, "Negotiations About the 'New Tunisia': Invocations of 'Freedom' and 'Democracy' in the Debates on the Role of Religion in PostRevolutionary Tunisia" (paper prepared for presentation at the 13th Mediterranean Research Meeting, European University Institute, Robert Shuman Center for Advanced Studies, Montecatini, Italy, March 21-23, 2012).
} 


\section{BIBLIOGRAPHY}

Addi, Lahouari. L'Algérie Et La Démocratie: Pouvoir Et Crise Du Politique Dans l'Algérie Contemporaine. [Algeria and democracy: Power and political crisis in contemporary Algeria]. La Découverte, 2010.

Almond, Gabriel A., and Sidney Verba. The Civic Culture: Political Attitudes and Democracy in Five Nations. London: Sage Publications, 1989.

Altınordu, Ateş. "The Politicization of Religion: Political Catholicism and Political Islam in Comparative Perspective.” Politics E Society 38, no. 4 (2010): 517551.

Anderson, John. "The Catholic Contribution to Democratization's 'Third Wave': Altruism, Hegemony or Self-interest?" Cambridge Review of International Affairs 20, no. 3 (2007): 383-399.

An-Na'im, Abdullahi Ahmed. Islam and the Secular State: Negotiating the Future of Sharia. Cambridge, MA: Harvard University Press, 2008.

Appleby, R. Scott. The Ambivalence of the Sacred: Religion, Violence, and Reconciliation. Oxford: Rowman \& Littlefield, 2000.

Appleby, R. Scott, and Martin E. Marty, eds. Fundamentalisms Comprehended (The Fundamentalism Project V. 5). Chicago: University of Chicago Press, 1995.

Ayoob, Mohammed. The Many Faces of Political Islam: Religion and Politics in the Muslim World. Ann Arbor, MI: University of Michigan Press, 2007.

Banfield, Edward C. The Moral Basis of a Backward Society. New York: The Free Press, 1967.

Bayat, Asef. "The Coming of a Post-Islamist Society." Critique 5, no. 9 (Autumn, 1996): 43-52.

Bellah, Robert. Religion in Human Evolution: From the Paleolithic to the Axial Age. Cambridge, MA: Harvard University Press, 2011.

Bellin, Eva. "Faith in Politics: New Trends in the Study of Religion and Politics." World Politics 60, no. 2 (2008): 315-47.

Boubekeur, Amel. "Post-Islamist Culture: A New Form of Mobilization?" History of Religions 47, no. 1 (2007): 75-94.

Brown, L. Carl. Religion and State: The Muslim Approach to Politics. New York: Columbia University Press, 2000. 
Brown, Nathan. "Dangers Ahead for Egypt." Op-Ed. Carnegie Endowment for International Peace, May 31, 2012. http://www.carnegieendowment. org/2012/05/31/dangers-ahead-for-egypt/b0xx.

Brownlee, Jason. "Unrequited Moderation: Credible Commitments and State Repression in Egypt." Studies in Comparative International Development 45, no. 4 (2010): 468-489.

Burgat, François, and William Dowell. The Islamic Movement in North Africa. Center for Middle Eastern Studies Middle East Monograph Series. Austin: University of Texas at Austin, 1993.

Casanova, José. Public Religions in the Modern World. Chicago: University of Chicago Press, 1994.

- "Civil Society and Religion: Retrospective Reflections on Catholicism and Prospective Reflections on Islam.” Social Research 68, no. 4 (2001): 1041-1080.

—. "Religion, Politics and Gender Equality: Public Religions Revisited." In $A$ Debate on the Public Role of Religion and its Social and Gender Implications. Gender and Development Programme Paper 5, United Nations Research Institute for Social Development (2009): 5-33.

Cavanaugh, William T. "If You Render Unto God What is God's, What is Left for Caesar?" The Review of Politics 71, no. 04 (2009): 607-619.

Charfi, Mohammed. Islam Et Liberté. [Islam and freedom]. Algiers: Casbah Editions, 2000.

Deeb, Lara. An Enchanted Modern: Gender and Public Piety in Shi'i Lebanon. New Jersey: Princeton University Press, 2008.

Deheuvels, Luc-Willy. Islam Et Pensée Contemporaine En Algérie: La Revue Al-Asâla (1971-1981). [Islam and contemporary thought in Algeria: The Al-Asâla review]. Éd. du CNRS, 1991.

Driessen, Michael."Public Religion, Democracy, and Islam: Examining the Moderation Thesis in Algeria." Comparative Politics 44, no. 2 (2012): 171-189.

- Religion and Democratization: Framing Political and Religious Identities in Catholic and Muslim Societies. New York: Oxford University Press, forthcoming.

Eisenstadt, Shmuel N. Comparative Civilizations and Multiple Modernities. Vol. 1. Leiden: Brill, 2003. 
—_. "Multiple Modernities." Daedalus (2000): 1-29.

El Fadl, Khaled Abou. And God Knows the Soldiers: The Authoritative and Authoritarian in Islamic Discourses. Lanham, MD: University Press of America, 2001.

Esposito, John L., and John O. Voll. Islam and Democracy. Oxford: Oxford University Press, 1996.

Frégosi, Franck. "Les Rapports Entre L'islam Et l'État En Algérie Et En Tunisie: De Leur Revalorisation à Leur Contestation." [Relationships between Islam and state in Algeria and Tunisia: From revaluation to contestation.] Annuaire De l'Afrique Du Nord 34 (1995): 103-123.

Ghannouchi, Rachid. Al-Hurrīyāt Al-āmmah Fìd Al-dawlah al-Islāmīyyah. [Public liberties in the Islamic state]. Beirut: Markaz Dirāsāt al-Wahdah al-'Arabīyah, 1993.

Gillespie, Michael A. The Theological Origins of Modernity. Chicago: University of Chicago Press, 2008.

Gorski, Philip S. "Historicizing the Secularization Debate: Church, State, and Society in Late Medieval and Early Modern Europe, Ca. 1300 to 1700." American Sociological Review 65 (2000): 138-167.

- The Disciplinary Revolution: Calvinism and the Rise of the State in Early Modern Europe. Chicago: University of Chicago Press, 2003.

Gorski, Philip S., and Ateş Altınordu. "After Secularization?" Annual Review of Sociology 34 (2008): 55-85.

Hale, William. "Christian Democracy and the AKP: Parallels and Contrasts." Turkish Studies 6, no. 2 (2005): 293-310.

Hashemi, Nader. Islam, Secularism, and Liberal Democracy: Toward a Democratic Theory for Muslim Societies. Oxford: Oxford University Press, 2009.

_. "The Multiple Histories of Secularism Muslim Societies in Comparison." Philosophy E' Social Criticism 36, nos. 3-4 (2010): 325-338.

Hefner, Robert W. Civil Islam: Muslims and Democratization in Indonesia. New Jersey: Princeton University Press, 2011.

Helmy, Khaled. "The Historical Process of State Regulation of Religion and Its Democratic Implications: Comparative Insights from the Regulation of Canon Law \& Shari'ah." Paper prepared for presentation at the 10th Mediterranean Research Meeting, European University Institute, Robert Shuman Center for Advanced Studies, Montecatini, Italy, March 25-28, 2009. 
Huntington, Samuel P. The Clash of Civilizations and the Remaking of World Order. New Delhi: Penguin, 1997.

—_. "Democracy's Third Wave." Journal of Democracy 2, no. 2 (1991): 12-34.

Kalyvas, Stathis N. "Commitment Problems in Emerging Democracies: The Case of Religious Parties.” Comparative Politics 32, no. 4 (2000): 379-398.

."Unsecular Politics and Religious Mobilization: Beyond Christian Democracy." In European Christian Democracy: Historical Legacies and Comparative Perspectives, edited by Thomas A. Kselman and Joseph A. Buttigieg, 293-320. Notre Dame, IN: University of Notre Dame Press, 2003.

Kalyvas, Stathis N., and Kees van Kersbergen. "Christian Democracy." Annual Review of Political Science 13 (2010): 183-209.

Kepel, Gilles. The Revenge of God: The Resurgence of Islam, Christianity, and Judaism in the Modern World. University Park, PA: Pennsylvania State University Press, 1994.

Kramer, Martin, ed. “The Mismeasure of Political Islam.” In The Islamism Debate, 161175. Tel Aviv: The Moshe Dayan Center for Middle Eastern and African Studies, 1997.

Künkler, Mirjam, and Julia Leininger. "The Multi-faceted Role of Religious Actors in Democratization Processes: Empirical Evidence from Five Young Democracies." Democratization 16, no. 6 (2009): 1058-1092.

Kuru, Ahmet T. Secularism and State Policies Toward Religion: The United States, France, and Turkey. New York: Cambridge University Press, 2009.

Laitin, David D. Hegemony and Culture: Politics and Change among the Yoruba. Chicago: University of Chicago Press, 1986.

Lapidus, Ira M. "The Separation of State and Religion in the Development of Early Islamic Society." International Journal of Middle East Studies 6, no. 4 (1975): 363-85.

- A History of Islamic Societies. Vol. 2. Cambridge: Cambridge University Press, 1988.

Lewis, Bernard. “The Roots of Muslim Rage.” The Atlantic 17, no. 4 (1990): 17-26.

Linz,Juan. “Totalitarianism and Authoritarianism." In Handbook of Political Science, vol. 3: Macropolitical Theory, edited by Fred I. Greenstein and Nelson W. Polsby, 336-350. Reading, MA: Addison-Wesley, 1975. 
Lipset, Seymour M., and Stein Rokkan, eds. Party Systems and Voter Alignments: Crossnational Perspectives. Vol. 7. New York: The Free Press, 1967.

Lovin, Robert W. Christian Realism and the New Realities. Cambridge: Cambridge University Press, 2008.

Lust-Okar, Ellen. "Divided They Rule: The Management and Manipulation of Political Opposition.” Comparative Politics 36, no. 2 (2004): 159-179.

Minkenberg, P. Michael. "Democracy and Religion: Theoretical and Empirical Observations on the Relationship Between Christianity, Islam and Liberal Democracy." Journal of Ethnic and Migration Studies 33, no. 6 (2007): 887-909.

Nasr, S. Vali. “The Rise of 'Muslim Democracy.” Journal of Democracy 16, no. 2 (2005): 13-27.

Philpott, Daniel. "Explaining the Political Ambivalence of Religion." American Political Science Review 101, no. 3 (2007): 505-525.

—_. "The Catholic Wave." Journal of Democracy 15, no. 2 (2004): 32-46.

_. "The Religious Roots of Modern International Relations." World Politics 52, no. 2 (2000): 206-245.

Pipes, Daniel. In the Path of God: Islam and Political Power. New Jersey: Transaction Books, 1983.

Pius XII, Pope. "Democracy and a Lasting Peace." Christmas Radio Message. December 25, 1944.

"Political Islam and Democracy, by German Foreign Minister Guido Westerwelle." Ikhwan Website, January 18, 2012. http://www.ikhwanweb.com/article. php?id=29566.

Putnam, Robert. Making Democracy Work: Civic Traditions in Modern Italy. New Jersey: Princeton University Press, 1994.

Riccardi, Andrea. Il "Partito Romano" Nel Secondo Dopoguerra, 1945-1954. [The "Roman Party" in the second post-war period, 1945-1954]. Brescia: Morcelliana, 1983.

Roy, Olivier. The Failure of Political Islam, translated by Carol Volk. Cambridge, MA: Harvard University Press, 1994.

Globalized Islam: The Search for a New Ummah. New York: Columbia University Press, 2004.

- Holy Ignorance: When Religion and Culture Part Ways, translated by Ros Schwartz. New York: Columbia University Press, 2010. 
- "The Transformation of the Arab World." Journal of Democracy 23, no. 3 (2012): 5-18.

Schwedler, Jillian. "Can Islamists Become Moderates? Rethinking the InclusionModeration Hypothesis.” World Politics 63, no. 02 (2011): 347-376.

- Faith in Moderation: Islamist Parties in Jordan and Yemen. Cambridge: Cambridge University Press, 2006.

Stepan, Alfred. Arguing Comparative Politics. Oxford: Oxford University Press, 2001.

Tamimi, Azzam S. Rachid Ghannouchi: A Democrat within Islamism. Oxford: Oxford University Press, 2001.

Taylor, Charles. A Secular Age. Cambridge: Cambridge University Press, 2007.

Tezcür, Güneş M. "The Moderation Theory Revisited: The Case of Islamic Political Actors." Party Politics 16, no. 1 (2010): 69-88.

Tibi, Bassam. "Why They Can't be Democratic." Journal of Democracy 19, no. 3 (2008): 43-48.

Toft, Monica Duffy, Daniel Philpott, and Timothy Samuel Shah. God's Century: Resurgent Religion and Global Politics. New York: W.W. Norton \& Co., 2011.

Voorhoeve, Maaike. "Negotiations About the 'New Tunisia': Invocations of 'Freedom' and 'Democracy' in the Debates on the Role of Religion in Post-Revolutionary Tunisia." Paper prepared for presentation at the 13th Mediterranean Research Meeting, European University Institute, Robert Shuman Center for Advanced Studies, Montecatini, Italy, March 21-23, 2012.

Walzer, Michael. The Revolution of the Saints: A Study in the Origins of Radical Politics. Cambridge, MA: Harvard University Press, 1982.

Warner, Carolyn M. Confessions of an Interest Group: The Catholic Church and Political Parties in Europe. New Jersey: Princeton University Press, 2000.

Webb, Leicester Chisholm. Church and State in Italy, 1947-1957. Melbourne: Melbourne University Press, 1958.

Weber, Max. Economy and Society: An Outline of Interpretive Sociology. Vol. 1. Berkeley, CA: University of California Press, 1978.

. The Protestant Ethic and the "Spirit" of Capitalism and Other Writings, edited and translated by Peter Baehr and Gordon C. Wells. New York: Penguin Classics, 2002. 
Wickham, Carrie Rosefsky. "The Path to Moderation: Strategy and Learning in the Formation of Egypt's Wasat Party." Comparative Politics 36, no. 2 (2004): 205-228.

Zagorin, Perez. How the Idea of Religious Toleration Came to the West. New Jersey: Princeton University Press, 2003.

Zeghal, Malika. Islamism in Morocco: Religion, Authoritarianism, and Electoral Politics, translated by George Holoch. Princeton: Markus Wiener Publishers, 2008. 


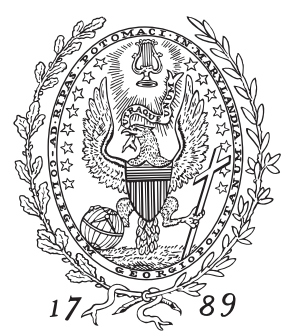

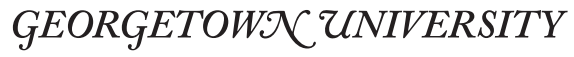

School of Foreign Service in Qatar

Center for International and Regional Studies

$$
\begin{gathered}
\text { P.O. Box } 23689 \\
\text { Doha, Qatar }
\end{gathered}
$$

http://cirs.georgetown.edu

Tel +974 44578400

Fax +974 44578401 


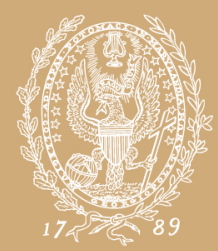

GEORGETOWNCUNIVERSITY

School of Foreign Service in Qatar

Center for International and Regional Studies

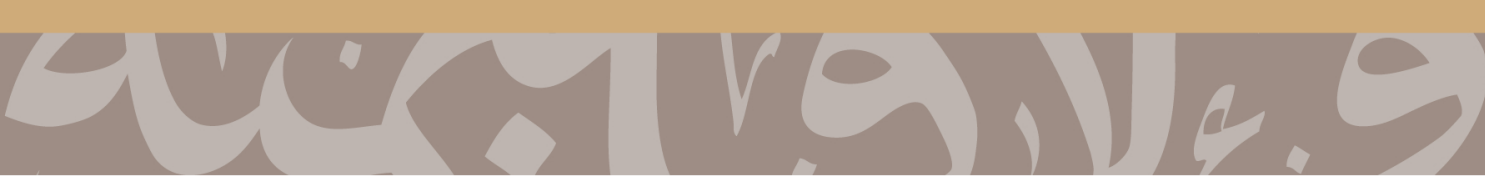

